Pengaruh Partisipasi Penyusunan Anggaran Dan Karakteristik Tujuan Anggaran

Terhadap Kinerja Manajerial Dengan Lingkungan Kerja Non Fisik Sebagai Variabel Moderasi, VOL. 12. No. 1 KOMPAK Tahun 2019.

\title{
PENGARUH PARTISIPASI PENYUSUNAN ANGGARAN DAN KARAKTERISTIK TUJUAN ANGGARAN TERHADAP KINERJA MANAJERIAL DENGAN LINGKUNGAN KERJA NON FISIK SEBAGAI VARIABEL MODERASI
}

\author{
Iwan Koerniawan, Eka Satria Wibawa
}

\section{SEKOLAH TINGGI ELEKTRONIKA DAN KOMPUTER}

\begin{abstract}
The purpose of this study is to analyze and provide empirical evidence about the influence of budgetary participation and characteristic of budget objectives on managerial job performance with non physical work environment as a moderasi.Populasi variables in this study are all leaders and financial officers in SMK Swasta in Semarang city listed in the structure of the division of school work in 2016 which amounted to 14 SMK and each - each taken 3 people so that the number of 42 respondents, while the sampling technique using the census method. Data analysis method used is Regression Moderation Analysis (MRA)

The result of hypothesis test 1 is known that the value of $t$ arithmetic $=3.012$ $>t$ table $=1.694$ with the number of significance $=0.003<\alpha=0.05$ (significant), so the hypothesis ( $\mathrm{H1}$ ) that the budgeting participation has a positive effect on the managerial job performance proven. The regression coefficient $\beta_{1}=0.567$ (positive sign), it can be interpreted that the higher the participation of budget preparation, the higher the managerial performance. Testing of hypothesis 2 is known that $t$ value $=$ 2.723 $t$ table $=1.694$ with significance number $=0.010<\alpha=0.05$ (significant), so hypothesis (H2) that characteristic of budget objective have positive effect to proven managerialjob performance. The coefficient of gradually $=0.279$ (benchmarked), it may be interpreted to be more clearly the characteristic of the budget objectives of the managerial level.

Testing of hypothesis 3 is known that $t$ value 2.484> $t$ table $=1.694$ with significance number $=0.026<\alpha=0.05$ (significant), so hypothesis $(\mathrm{H} 3)$ that non working environment moderate moderate positive influence of budgetary participation to performance of managerial job performance proven. Hypothesis 4 testing is known that the value of $t$ arithmetic 2.333> $t$ table $=1.694$ with the number of significance $=0.032<\alpha=0.05$ (significa

$n t)$. Thus the hypothesis ( $\mathrm{H} 4)$ that a non-physical work environment moderately positively influences the characteristics of the budget objective against proven managerial job performance. Interaction test results show $\beta_{4}=0.163$ (positive sign), it can be interpreted that the existence of conducive non-physical work environment will strengthen the influence of characteristic of budget objectives on managerial job performance.
\end{abstract}

Keywords: Budgetary participation, budget objective characteristics, non-physical work environment, managerial job performance 


\section{Pendahuluan}

Pasar global telah melanda
sebagai konskuensi
dunia produk
perdagangan bebas dimana produs
dan jasa bebas keluar masuk suatu
negara. Masyarakat EkonomiASEAN
yang dimulai tahun 2016, suka tidak
suka harus diterima dengan tangan
terbuka. Hal ini akan memicu
persaingan antar perusahaan maupun
antar organisasi semakin yang ketat,
kejadian di masa yang akan datang
menjadi sulit untuk diprediksikan
sehingga proses perencanaan
organisasi menjadi masalah (Chenhall
dan Moris, 1986 dalam Aziz,
2011).Bagi manajer, kondisi ini menjadi tantangan untuk dapat mempertahankan dan meningkatkan kinerjanya. Kinerja manajerial adalah hasil secara periodik operasional suatu manajer berdasarkan sasaran, standar, dan kriteria yang telah ditetapkan sebelumnya (Mulyadi, 2010: 55). Selain itu kinerja manajerial merupakan keluaran (output) yang menggunakan masukan (input) selama periode tertentu yang telah ditetapkan sebelumnya.

Pembuatan rencana anggaran dalam satuan organisasi membutuhkan partisipasi semua bagian yang berkepentingan dengan organisasi. Hal ini ditujukan agar dalam membuat perencanaan anggaran dapat disusun secara akurat, tepat sasaran, dan efisien di semua bagian organisasi (Sasongko dkk, 2013). Partisipasi penyusunan anggaran merupakan pendekatan yang secara umum dapat meningkatkan kinerja yang pada akhirnya dapat meningkatkan efektivitas. Wahyudin (2007) menyatakan bahwa partisipasi sebagai alat untuk mencapai tujuan, partisipasi juga sebagai alat untuk mengintegrasikan kebutuhan individu dan organisasi.

Selain itu perencanaan anggaran juga ditujukan untuk mengendalikan penggunaan sumber dana yang digunakan untuk mencapai tujuan organisasisehingga anggaran harus mempunyai tujuan yang jelas, (Kenis, 1979). Manajer yang memiliki tujuan anggaran yang terlalu ketat secara signifikan memiliki ketegangan kerja tinggi, motivasi kerja rendah, kinerja anggaran, dan efisiensi biaya dibandingkan untuk anggaran memiliki tujuan anggaran yang ketat tetapi dapat dicapai (Kenis, 1979).

Beberapa penelitian mengenai hubungan antara partispasi anggran dan tujuan anggaran dengan kinerja manajerial telah dilakukan. Hasil penelitian Aziz (2011) bahwa partisipasi penyusunan anggaran berpengaruh positif dan signifikan terhadap kinerja manajerial. Demikian juga penelitian sucirawati \& sari (2017)Juga menunjukan bahwa partisipasi penyusunan anggaran berpengaruh positif dan signifikan terhadap kinerja manajerial, sedangkan hasil penelitian Yunita (2001menunjukan bahwa partisipasi penyusunan anggaran berpengaruh negatif dan signifikan terhadap kinerja manajerial. Kemudian penelitian khotimah (2010) menemukanbahwa karaktristik tujuan penyusunan anggaran berpengaruh positif dan signifikan terhadap kinerja manajerial. Penelitian Bhakti, Pituringsih \& Widiastuty (2015 Juga menemukanbahwa karaktristik tujuan 
penyusunan anggaran berpengaruh positif dan signifikan terhadap kinerja manajerial. Sedangkan hasil penelitian Ramandei menemukan bahwa partisipasi penyusunan anggaran berpengaruh negatif dan signifikan terhadap kinerja manajerial.

Adanya perbedaan dari hasil penelitian-penelitian terdahulu menarik perhatian peneliti untuk melanjutkan penelitian ini dengan memasukkan variabel lingkungan kerja non fisik sebagai variabel moderasi.

Penelitian ini memusatkan penelitian pada jajaran pimpinan dan pejabat keuangan di SMK Swasta di Kota Semarang, yang telah melaksanakan penganggaran dengan mengacu pada pedoman pengelolaan keuangan lembaga pendidikan SMK Swasta. Berbeda dengan pengelolaan keuangan organisasi pemerintah dan perusahaan swasta nasional pada umumnya.

Alasan peneliti untuk menganalisis hal tersebut pada SMK Swasta di Kota Semarang sebagai fenomena penelitian, karena:

1. Saat ini pemerintah sedang giat dan gencarnya mendukung dan memromosikan SMK sebagai sebuah alternatif pendidikan solusi yang bisa mengentaskan persoalan pendidikan baik teknis/skill dan ketenagakerjaan, yang tentu saja telah banyak alokasi dana/anggaran yang telah dikeluarkan. Dibutuhkan public accountability yang mampu dipertanggungjawabkan.

2. Jajaran pimpinan dan pejabat keuangan dijadikan responden dalam penelitian ini adalah subjek langsung penganggaran yaitu sebagai perencana, pelaksana, dan penanggungjawab anggaran untuk program dan kegiatan di SMK Swasta di Kota Semarang, sehingga responden memiliki kaitan langsung dengan permasalahan yang akan diteliti.

\section{LANDASAN TEORI Resource-Based View (RBV Theory) \\ Teori RBV menjelaskan} pengaruh partikularitas tujuan anggaran terhadap kinerja manajerial. Barney (1991) dalam Arifian (2011) menggambarkan teori RBV sebagai sustained competitive advantange, penggunaan dan pengembangan sumber daya tertentu untuk mendapatkan keuntungan kompetitif jangka pendek dan kemudian mempertahankannya.budaya perusahaan dan teknologi.

\section{Teori Keagenan (Agency Theory)}

Teori keagenan menyatakan bahwa hubungan keagenan merupakan sebuah persetujuan (kontrak) di antara dua pihak, yaitu prinsipal dan agen, di mana prinsipal memberi wewenang kepada agen untuk mengambil keputusan atas nama prinsipal (Jensen dan Meckling, 1976). Yovita (2011) menjelaskan bahwa teori keagenan merupakan cabang dari game theory yang mempelajari suatu model kontraktual yang mendorong agen untuk bertindak bagi prinsipal saat kepentingan agen bisa saja bertentangan dengan kepentingan prinsipal.

\section{Kinerja Manajerial}

Kinerja manajerial adalah hasil secara periodik operasional suatu manajer berdasarkan sasaran, standar, dan kriteria yang telah ditetapkan sebelumnya (Mulyadi, 2010: 55). Selain itu kinerja manajerial merupakan keluaran (output) yang 
menggunakan masukan (input) selama periode tertentu yang telah ditetapkan sebelumnya. Menurut Mahoney et al (1963) dalam Mardiyah (2005:568) menyatakan kinerja adalah hasil kerja yang dapat dicapai oleh seseorang atau sekelompok orang dalam suatu organisasi, sesuai dengan wewenang dan tanggung jawab masing-masing dalam rangka mencapai tujuan organisasi. Kinerja manajerial adalah kinerja individu anggota organisasi dalam kegiatankegiatan manajerial antara perencanaan, investigasi, pengkoordinasian, pengaturan staf, negosiasi, perwakilan, dan kinerja secara keseluruhan.

\section{Partisipasi Penyusunan Anggaran}

Anthony dan Govindarajan (2005) menyatakan bahwa terdapat dua pendekatan utama dalam penyusunan anggaran, yaitu pendekatan dari atas ke bawah (top down approach) dan pendekatan dari bawah ke atas (bottom up approach). Pendekatan lain merupakan gabungan dari kedua pendekatan tersebut, yaitu pendekatan partisipas. Pada top down approach, anggaran yang harus dilaksanakan oleh manajer pusat pertangunggjawaban ditetapkan oleh manajemen puncak. Keuntungan pendekatan ini antara lain proses anggaraan yang membutuhkan waktu yang lebih hemat, dukungan kuat dari manajemen puncak dalam pengembangan anggran serta prosesnya menjadi lebih mudah dikendalikan oleh manajemen puncak.

\section{Karakteristik Tujuan Anggaran}

Karakteristik tujuan anggaran adalah range dari "sangat longgar dan mudah dicapai" sampai dengan "sangat ketat dan tidak dapat dicapai' . Tujuan anggaran yang mudah dicapai akan gagal untuk memberikan suatu tantangan untuk partisipan dan memiliki sedikit pengaruh motivasi. Setidaknya tujuan yang sangat ketat dan tidak dapat dicapai mengarahkan pada perasaan gagal, frustasi, dan tingkat aspirasi rendah. $\mathrm{Hal}$ ini mengindikasikan bahwa yang menjadi tingkat kesulitan untuk tujuan anggaran adalah "ketat, tetapi dapat dicapai" (Kenis, 1979).

\section{Lingkungan Kerja Non Fisik}

Menurut Anoraga dan Widiyanti

(2002), lingkungan kerja adalah merupakan suatu lingkungan dimana para karyawan tersebut bekerja. Lingkungan kerja yang buruk secara langsung maupun tak akan dapat mengganggu karyawan dalam bekerja, sebaliknya jika lingkungan kerja baik akan dapat menunjang kinerja karyawan (Nitisemito, 2003).

\section{METODE PENELITIAN Jenis dan Sumber Data}

Berdasarkan skala, jenis data yang digunakan untuk mengukur variabelvariabel yang diuji adalah data berskala ordinal. Sedangkan berdasarkan sumber perolehannya data dapat dibedakan menjadi data primer dan sekunder. Data primer yaitu data yang dikumpulkan sendiri oleh peneliti, sedangkan data sekunder yaitu data yang tidak dikumpulkan sendiri oleh peneliti (Marzuki, 2002 ). Data primer dalam penelitian ini adalah jawaban responden yang dikumpulkan melalui kuesioner sedangkan data sekunder dalam penelitian ini meliputi data mengenai gambaran umum obyek penelitian ( SMK Swasta di Kota Semarang), literature, jurnal dan sebaginya

\section{Populasi dan Teknik Pengambilan} Sampel 


\begin{abstract}
Populasi adalah gabungan dari seluruh elemen yang berbentuk peristiwa, hal, atau orang yang memiliki karakteristik yang serupa yang menjadi pusat perhatian seorang peneliti karena itu dipandang sebagai sebuah semesta penelitian. Sedang elemen populasi (sampel) adalah setiap anggota dari populasi yang diamat (Ferdinand, 2006). Populasi dalam penelitian ini adalah seluruh pimpinan dan pejabat keuangan yang ada di SMK Swasta di Kota Semarang yang terdaftar dalam struktur pembagian kerja sekolah tahun 2016 yang berjumlah 14 SMK dan masing - masing diambil 3 orang sehingga jumlahnya sebanyak 42 orang responden. Adapun teknik pengambilan sampel menggunakan metode sensus, yaitu mengambil semua populasi sebagai sampel (Arikunto, 2006).

\section{Metode Pengumpulan Data}

Metode dokumenter yaitu cara pengumpulan data dengan menggunakan dokumen-dokumen dengan penelitian tersebut atau mencari data mengenai hal-hal atau variabel berupa catatan, transkip, surat kabar, buku-buku, majalah, prasasti, ledger, notulen rapat, agenda, dan sebagainya (Arikunto, 2006). Data yang diperoleh dari metode dokumentasi adalah laporan akuntabilitas kerja instansi lembaga pendidikan SMK tahun terkait untuk mengetahui kinerja manajerial.

1. Metode Kuesioner

Metode kuesioner ini dengan menyebarkan kueisoner yang di dalamnya diberikan sekumpulan pertanyaan secara tertulis yang disusun secara sistematis mengenai masalah-masalah yang berkaitan dengan topik.Pertanyaan berbentuk pertanyaan tertutup diukur dengan skala Likert (Ghozali, 2011).

\section{Variabel Penelitian dan Definisi Operasionalnya}

Variabel terikat (dependent variable) dalam penelitian ini adalah kinerja manajerial $(\mathrm{Y})$, sedangkan variabel terikat (independent variable) adalah partisipasi penyusunan anggaran (X1) dan karakteristik tujuan anggaran (X2) selanjutnya variabel moderasi (moderatingvariable) adalah lingkungan kerja non fisik (Z).

\section{Teknis Analisis Penelitian}

a. Uji Validitas

Uji validitas digunakan untuk mengukur sah atau valid tidaknya suatu kuesioner

b. Uji Reliabilitas

Uji reliabilitas, yaitu istilah yang dipakai untuk menunjukkan sejauh mana suatu hasil pengukur relatif konsisten apabila pengukuran dilakukan dua kali atau lebih.

Uji Asumsi Klasik

Model regresi merupakan model yang menghasilkan estimator linear tidak bias yang terbaik (Best Linear Unbias Estimate / BLUE).

a. Uji Normalitas

Pengujian ini bertujuan untuk menguji apakah dalam model regresi, variabel dependen dan variabel independen keduanya mempunyai distribusi normal ataukah tidak.

b. Uji Autokorelasi

Uji autokorelasi bertujuan untuk menguji apakah dalam model regresi ada korelasi antara kesalahan pengganggu pada periode $t$ dengan kesalahan pada periode sebelumnya. 
Pengaruh Partisipasi Penyusunan Anggaran Dan Karakteristik Tujuan Anggaran Terhadap Kinerja Manajerial Dengan Lingkungan Kerja Non Fisik Sebagai Variabel Moderasi, VOL. 12. No. 1 KOMPAK Tahun 2019.

c. Uji Multikolinieritas

Uji multikolinieritas bertujuan untuk menguji apakah model regresi ditemukan adanya korelasi antara variabel bebas (independen).

d. Uji Heteroskedestisitas

Uji heteroskedastisitas bertujuan untuk menguji apakah dalam model regresi terjadi ketidaksamaan varian dari residual satu pengamatan ke pengamatan yang lain

e. Uji Kelayakan Model

Menurut Ghozali (2011) uji kelayakan yang digunakan meliputi :

Koefisien determinasi

Koefisien determinasi (adjusted $\mathrm{R}^{2}$ ) digunakan untuk mengukur seberapa besar kemampuan model dalam menerangkan variasi variabel terikat.

Uji $F$

Kriteria yang digunakan :

- Jika nilai $F$ hitung > F tabel, maka signifikan dan jika nilai $\mathrm{F}$ hitung $<\mathrm{F}$ tabel, maka tidak signifikan

- Jika angka signifikansi $<$

$=0,05$, maka signifikan dan jika angka signifikansi > 0,05 , maka tidak signifikan

Uji Hipotesis

Uji hipotesis yang digunakan yaitu uji signifikansi individual (t test) untuk menguji signifikansi variabel bebas yang terdapat dalam persamaan regresi secara individu berpengaruh terhadap nilai variabel terikat. Kriteria yang digunakan :

a.

Jika $\mathrm{t}$ hitung $>\mathrm{t}$ tabel (signifikan) dan jika $\mathrm{t}$ hitung $\leq \mathrm{t}$ tabel (tidak signifikan) b.

Jika angka signifikansi $<\alpha=0,05$ (signifikan)dan jika angka signifikansi $>0,05$ ( tidak signifikan)

1. Analisis Regresi Moderasi (Uji Interaksi)

Moderated Regression Analyzis (MRA) atau Analisis Regresi Moderasi adalah aplikasi khusus regresi linier berganda yang mengandung unsur interaksi(perkalian dua atau lebih variabel independen).

Model persamaan regresi yang digunakan adalah sebagai berikut (Ghozali, 2011) :

$$
\begin{aligned}
& Y=\square_{1} X_{1}+\square_{2} X_{2}+\square_{3}\left(X_{1} . Z\right)+ \\
& \left.\square_{4}\right) \\
& \left(X_{2} Z\right)+e \\
& \text { Dimana: } \\
& Y: \text { Kinerja Manajerial } \\
& X_{1}: \text { Partisipasi Penyusunan } \\
& \text { Anggran } \\
& X_{2}: \text { Karakteristik Tujuan Anggran } \\
& Z: \text { Lingkungan Kerja Non Fisik } \\
& \square \quad: \text { Koefisiensi } \\
& \text { Regresi e : Error / } \\
& \text { residu }
\end{aligned}
$$

\section{Proses dan Hasil Analisis}

Uji Validitas

Uji validitas digunakan untuk mengukur sah atau tidaknya suatu kuesioner. Uji validitas ini dilakukan dengan membandingkan $r$ hitung dan $r$ tabel. Apabila $r$ hitung $>r$ tabel maka kuesioner dinyatakan valid. Berdasarkan print out komputer (lampiran-4) dapat disusun tabel berikut ini.

Tabel

Hasil Pengujian Validitas Kuesioner 
Pengaruh Partisipasi Penyusunan Anggaran Dan Karakteristik Tuj ınn Anggaran Terhadap Kinerja Manajerial Dengan Li ngkungan Kej a Non Fi sik Sebaga Variabel Moderasi, VOL. 12. No. 1 KOMPAK Tahun 2019.

\begin{tabular}{|c|c|c|c|c|}
\hline Variabel & Indikator & $\begin{array}{ll}\text { r hitung } \\
\text { (Corrected Item Total } \\
\text { Correlation) }\end{array}$ & $>$ & $\begin{array}{l}r \text { tabel } \\
(\alpha=0,05)\end{array}$ \\
\hline $\begin{array}{l}\text { Partisipasi Penyusunan } \\
\text { Anggaran (X1) }\end{array}$ & $\begin{array}{l}\mathrm{X} 1.1 \\
\mathrm{X} 1.2 \\
\mathrm{X} 1.3 \\
\mathrm{X} 1.4\end{array}$ & $\begin{array}{l}0,529 \\
0.519 \\
0,592 \\
0,564\end{array}$ & $\begin{array}{l}> \\
> \\
>\end{array}$ & $\begin{array}{l}0,304 \\
0,304 \\
0,304 \\
0,304\end{array}$ \\
\hline $\begin{array}{cc}\text { Karakteristik } & \text { Tujuan } \\
\text { Anggaran }(X 2) & \end{array}$ & $\begin{array}{l}\times 2.1 \\
\times 2.2 \\
\times 2.3 \\
\times 2.4\end{array}$ & $\begin{array}{l}0,561 \\
0,542 \\
0,483 \\
0,531\end{array}$ & $\begin{array}{l}> \\
> \\
>\end{array}$ & $\begin{array}{l}0,304 \\
0,304 \\
0,304 \\
0,304\end{array}$ \\
\hline $\begin{array}{l}\text { Lingkungan Kerja Non } \\
\text { Fisik }(Z)\end{array}$ & $\begin{array}{l}\text { Z.1 } \\
\text { Z.2 } \\
\text { Z.3 } \\
\text { Z.4 } \\
\text { Z.5 }\end{array}$ & $\begin{array}{l}0,808 \\
0,540 \\
0,838 \\
0,823 \\
0,593\end{array}$ & $\begin{array}{l}> \\
> \\
> \\
> \\
>\end{array}$ & $\begin{array}{l}0,304 \\
0,304 \\
0,304 \\
0,304 \\
0,304\end{array}$ \\
\hline Kinerja Manajerial $(\mathrm{Y})$ & $\begin{array}{l}\text { Y. } 1 \\
\text { Y. } 2 \\
\text { Y. } 3 \\
\text { Y. } 4 \\
\end{array}$ & $\begin{array}{l}0,785 \\
0,633 \\
0,568 \\
0,762 \\
\end{array}$ & $\begin{array}{l}> \\
> \\
>\end{array}$ & $\begin{array}{l}0,304 \\
0,304 \\
0,304 \\
0,304 \\
\end{array}$ \\
\hline
\end{tabular}

Sumber : Data primer yang diolah, 2017

Tabel di atas menunjukkan bahwa semua vari abe kuesione val d karena masing-masing item memenuhi syarat yaitu nilai corrected item total correlation atau $r$ hitung > r tabel=0,304 ( $\mathrm{N}=42, \square=$ 0,05 )

Uji reliabilitas digunakan untuk mengukur keandalan ajwaban da ri sua th pertanyaan atau dengan kata lain untuk mengetahui derajat stabilitas alat ukur

Uji F

Hasil Uji $F$ dapat dijelaskan berdasarkan tabel di bawah ini.

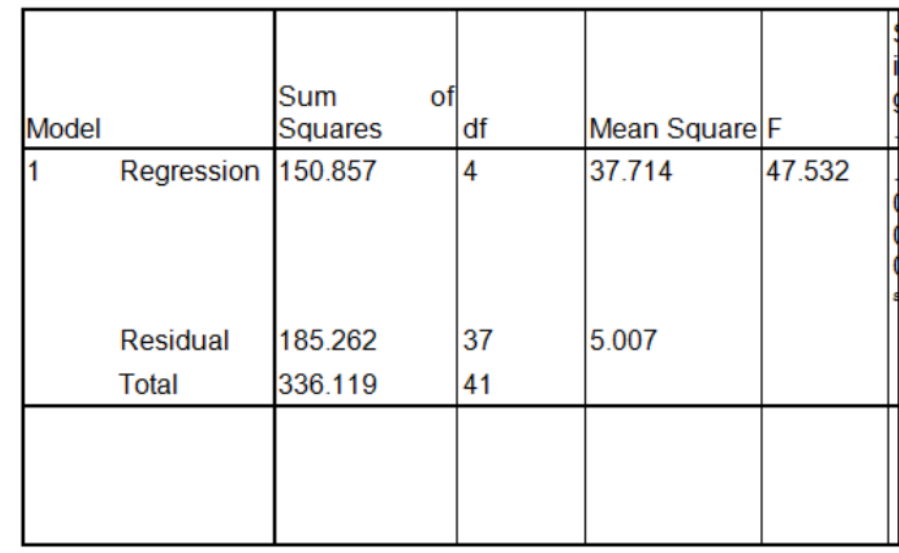

Sumber : Data primer yang diolah, 2017

Tabel di atas menunjukkan bahwa nilai $\mathrm{F}$ hitung $=47,532>\mathrm{F}$ tabel $=2,61$. $\left(\mathrm{df}_{1}=\mathrm{k}=4\right.$ dan $\mathrm{df}_{2}=\mathrm{n}-\mathrm{k}-1=42-4-$ $1=37, \square=0,05$ ) , dengan angka signifikansi $\quad=\quad 0,000<\square=$ 0,05 (signifikan).

\section{Pengujian Hipotesis}

4.2.1. Uji Hipotesis Pengaruh Partisipasi Penyusunan AnggaranDan Karakteristik Tujuan AnggaranTerhadap Kinerja Manajerial Dengan Lingkungan Kerja Non FisikSebagai Variabel Moderasi

Pengujian hipotesis dapat dilakukan berdasarkan tabel di bawah ini: 
Pengaruh Partisipasi Penyusunan Angga an Dan Ka akte iśt lik Tu yian Anggaran Terhadap Kinerja Manajerial Dengan Lingkungan Ke ra Non F ṡik Sebagai Variabel Moderasi, VOL. 12. No. 1 KOMPAK Tahun 2019.

Sumber : Data primer yang diolah, 2017

Berdasarkan tabel di atas dapat dilakukan pengujian hipotesis sebagai berikut :

1. Pengujian hipotesis $1(\mathrm{H} 1)$ :

- Ho : $\square_{1}=0$ :

$$
\begin{aligned}
& \text { Partisipasi } \\
& \text { penyusunan } \\
& \text { anggarantidak } \\
& \text { berpengaruh } \\
& \text { terhadap kinerja } \\
& \text { manajerial }
\end{aligned}
$$

- Ha : $\square_{1}>0$ :

$$
\begin{aligned}
& \text { Partisipasi } \\
& \text { penyusunan }
\end{aligned}
$$$$
\text { anggaran }
$$$$
\text { berpengaruh }
$$$$
\text { positif terhadap }
$$$$
\text { kinerja }
$$$$
\text { manajerial }
$$

2. Pengujian hipotesis $2(\mathrm{H} 2)$ :

- Ho : $\square_{2}=0$ : Karakteristik tujuan anggaran tidak berpengaruh terhadap kinerja manajerial

- Ha : $\square 2>0$ : Karakteristik tujuan anggaran berpengaruh positif terhadap kinerja manajerial

3. Pengujian Hipotesis $3(\mathrm{H} 3)$ :

- Ho: $\square_{3}=0$ : Lingkungan kerja non fisik 


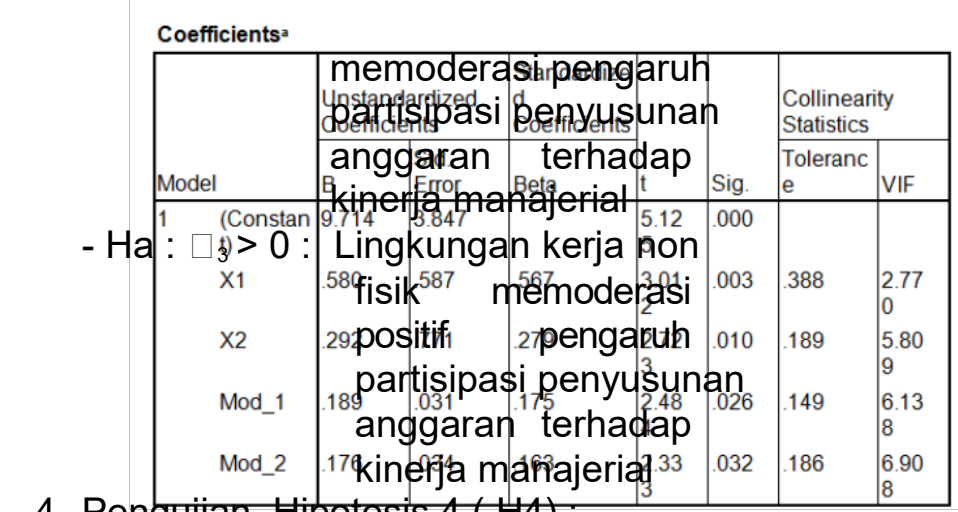

4. Pengujian Hipotesis $4(H 4)$ :

- Ho: $\square_{4}=0$ : Lingkungan kerja non

$$
\begin{aligned}
& \text { fisiktidak } \\
& \text { memoderasi } \\
& \text { pengaruh karakteristik } \\
& \text { tujuan } \\
& \text { anggaran terhadap } \\
& \text { kinerja manajerial }
\end{aligned}
$$

- $\mathrm{Ha}: \square 4>0$ : Lingkungan kerja non fisik

$$
\begin{array}{lr}
\text { memoderasi } & \text { positif } \\
\text { pengaruh karakteristik }
\end{array}
$$$$
\text { tujuan anggaran terhadap }
$$$$
\text { kinerja manajerial }
$$

\section{Analisis Regresi Pengaruh Partisipasi Penyusunan Anggaran Dan KarakteristikTujuan AnggaranTerhadap Kinerja Manajerial Dengan Lingkungan Kerja Non Fisik Sebagai Variabel Moderasi}

Berdasarkan tabel 4.29 dapat diketahui bahwa koefisien regresi ( beta) atau $\beta_{1}=0,567, \beta_{2}=0,279, \beta_{3}=$ 0,175 dan $\beta_{4}=0,163$ sehingga dapat disusun persamaan regresi moderasi sebagai berikut :

$Y=\beta_{1} X_{1}+\beta_{2} X_{2}+\beta_{3}\left(X_{1} . Z\right)+\beta_{4}$ $\left(X_{2} \cdot Z\right)+e$

Sehingga :

$$
\begin{aligned}
& Y=0,567 X_{1}+0,279 X_{2}+0,175 \\
& \left(X_{1} Z\right)+0,163\left(X_{2} Z\right)+e
\end{aligned}
$$



Variabel Moderasi, VOL. 12. No. 1 KOMPAK Tahun 2019.

Dengan demikian dapat dijelaskan bahwa :

1. Koefisien regresi $\beta_{1}=$ 0,567 ( bertanda positif), hal ini menunjukkan adanya pengaruh positif variabel partisipasi penyusunan anggaran (X1) terhadap kinerja manajerial $(\mathrm{Y})$ dan dapat diinterpretasikan bahwa semakin tinggi partisipasi penyusunan anggaranmaka semakin tinggi pula kinerja manajerial

2. Koefisien regresi $\beta_{2}=$ 0,279 ( bertanda positif), hal ini menunjukkan adanya pengaruh positif variabel karakteristik tujuan anggaran $\left(\mathrm{X}_{2}\right)$ terhadap kinerja manajerial $(\mathrm{Y})$ dan dapat diinterpretasikan bahwa semakin jelas karakteristik tujuan anggaran maka semakin tinggi kinerja manajerial.

3. Uji interaksi dari analisis terhadap persamaan di atas menunjukkan $\beta_{3}=0,175$ ( bertanda positif), hal ini berarti variabel lingkungan kerja non fisik(Z) memoderasi positif pengaruh variabel partisipasi penyusunan anggaran (X1) terhadap kinerja manajerial (Y) dan dapat diinterpretasikan bahwa adanya lingkungan kerja non fisikyang kondusif akan memperkuat pengaruh partisipasi penyusunan panggaranterhadap kinerja manajerial

4. Uji interaksi dari analisis terhadap persamaan di atas juga menunjukkan $\beta_{4}=0,163$ ( bertanda positif), hal ini berarti variabel lingkungan kerja non $\operatorname{fisik}(Z)$ memoderasi positif pengaruh variabel karakteristik tujuan anggaran $\left(\mathrm{X}_{2}\right)$ terhadap kinerja manajerial (Y) dan dapat diinterpretasikan bahwa adanya lingkungan kerja non fisikyang kondusif akan memperkuat pengaruh karakteristik tujuan anggaran terhadap kinerja manajerial.

\section{Pembahasan}

Hasil pengujian hipotesis 1 menunjukkan bahwa partisipasi penyusunan anggaran berpengaruh positif ( $\left.\beta_{1}=0,567\right)$ dan signifikan (sig. $=0,003$ ) terhadap kinerja manajerial sehingga hipotesis $(\mathrm{H} 1)$ terbukti dan dapat diinterpretasikan bahwa semakin tinggi artisipasi penyusunan anggaran maka semakin tinggi pula kinerja manajerialpengelola keuangan di SMK Swasta d Kota Semarang

Hasil uji interaksi menunjukkan bahwa lingkungan kerja non fisik memoderasi positif $\left(\beta_{3}=0,175\right)$ dan signifikan (sig. = 0,026 ) pengaruh partisipasi penyusunan anggaran terhadap kinerja manajerial sehingga hipotesis $(\mathrm{H} 3)$ terbukti dan dapat diinterpretasikan bahwa adanya lingkungan kerja non fisik yang kondusif akan memperkuat pengaruh partisipasi penyusunan panggaran terhadap kinerja manajerial pengelola keuangan di SMK Swasta d Kota Semarang

Hasil uji interaksi juga menunjukkan bahwa lingkungan kerja non fisik memoderasi positif $\left(\beta_{4}=0,163\right)$ dan signifikan $\quad($ sig. $=0,026)$ pengaruh partisipasi penyusunan anggaran terhadap kinerja manajerial sehingga hipotesis $(\mathrm{H} 4)$ terbukti dandapat diinterpretasikan bahwa adanya lingkungan kerja non fisik yang kondusif akan memperkuat pengaruh karakteristik tujuan anggaran terhadap kinerja manajerial pengelola keuangan di SMK Swasta d Kota Semarang.

\section{Simpulan}

1. Pengujian hipotesis 1 diketahui bahwa nilai $\mathrm{t}$ hitung $=3,012>\mathrm{t}$ tabel = 1,694 dengan angka signifikansi $=0,003<\square=0,05$ 

Variabel Moderasi, VOL. 12. No. 1 KOMPAK Tahun 2019.

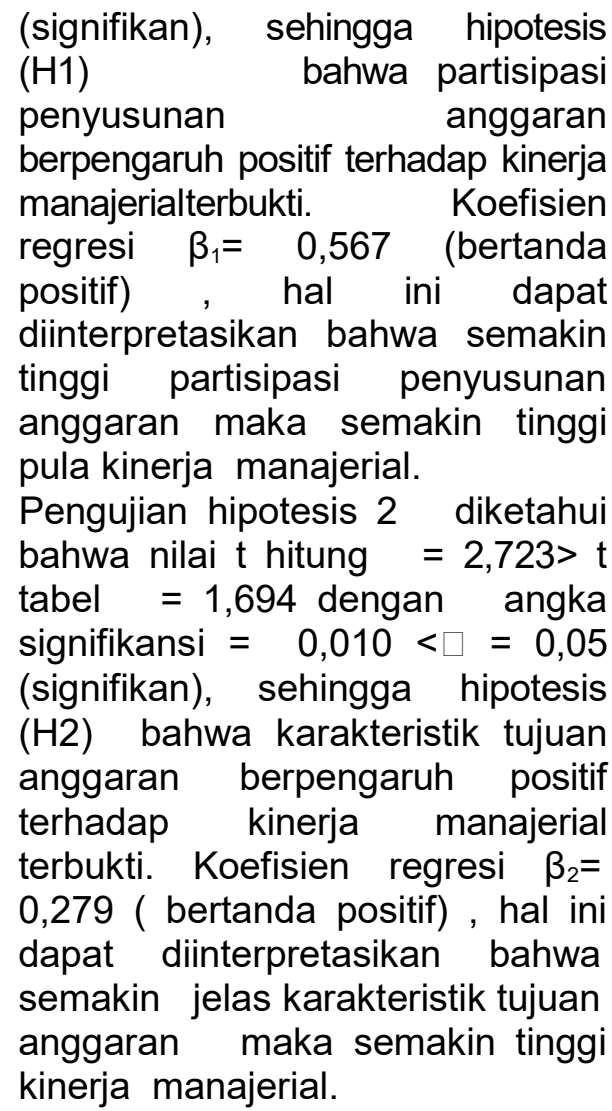

3. Pengujian hipotesis 3 diketahui bahwa nilai t hitung $2,484>t$ tabel $=1,694$ dengan angka signifikansi $=0,026<\square=0,05$ (signifikan), sehingga hipotesis $(\mathrm{H} 3)$ bahwa lingkungan kerja non fisik memoderasi positif pengaruh partisipasi penyusunan anggaran terhadap kinerja kinerja manajerialterbukti. Hasil uji interaksi menunjukkan $\quad \beta_{3}=0,175$ ( bertanda positif), hal ini dapat diinterpretasikan bahwa adanya kinerja manajerial.yang kondusif akan memperkuat pengaruh partisipasi penyusunan anggaranterhadap kinerja manajerial.

4. Pengujian hipotesis 4 diketahui bahwa nilai $t$ hitung $2,333>t$ tabel $=1,694$ dengan angka signifikansi $=0,032<\square=0,05$ (signifikan). Dengan demikian maka hipotesis (H4) bahwa lingkungan kerja non fisik memoderasi positif pengaruh karakteristik tujuan anggaran terhadap kinerja manajerial terbukti. Hasil uji interaksi menunjukkan $\beta_{4}=0,163$ ( bertanda positif) , hal ini dapat diinterpretasikan bahwa adanya iklim organisasiyang kondusif akan memperkuat karakteristik tujuan anggaran terhadap kinerja manajerial.

\section{Implikasi Kebijakan}

1. Hasil penelitian ini juga menunjukkan bahwa partisipasi penyusunan

anggaranberpengaruh positif terhadap kinerja manajerial. Hal ini berimplikasi pada perlunya peningkatan partisipasi penyusunan anggaranmelalui:

a. Meningkatkan komitmen para pengelola keuangan SMK swasta dengan melibat mereka dalam mengambil keputusan yang berkaitan dengan perencanaan anggaran.

b. Perlu memberikan kepercayaan dan tanggungjawab yang lebih besar kepada pengelola keuangan pada SMK swasta sehingga mereka akan berusaha meningkatkan partisipasinya dalam penyusunan anggaran

2. Hasil penelitian ini juga menunjukkan bahwa karakteristik tujuan anggaran berpengaruh positif terhadap kinerja manajerial.Hal ini berimplikasi pada perlunya meningkatkan 
Pengaruh Partisipasi Penyusunan Anggaran Dan Karakteristik Tujuan Anggaran Terhadap Kinerja Manajerial Dengan Lingkungan Kerja Non Fisik Sebagai Variabel Moderasi, VOL. 12. No. 1 KOMPAK Tahun 2019.

kejelasan karakteristik tujuan anggaran melalui :

a. Perlu adanya sosialisasi yang lebih intensif mengenai karakteristik tujuan anggaran sehingga akan meningkatkan upaya para pengelola keuangan dalam mencapai tujuan anggaran tersebut

b. Perlu adanya program pelatihan guna meningkatkan pengetahuan dan keahlian para pengelola keuangan SMK swasta sehingga mereka akanmeningkatkan pemahaman mereka terhadap karakteristik tujuan anggaran.

2. Hasil penelitian ini menunjukkan bahwa lingkungan kerja non fisik memoderasi positif pengaruh partisipasi penyusunan anggarandan karakteristik tujuan anggaran terhadap kinerja manajerial.Hal ini berimplikasi pada perlunya menciptakan lingkungan kerja non fisik yang kondusif melalui :

a. Perlu menciptakan suasana kerja yang harmonis sehingga tercipta lingkungan yang kondusif sehingga akan meningkatan kinerja manajerial

b. Perlu meingkatkan kerjasama yang lebih erat diantara individu di sekolahini sehinga akan menunjang peningkatan kinerja manajerial

\section{Keterbatasan Penelitian}

1. Variabel yang mempengaruhi kinerja pegawai dalam penelitian ini terbatas hanya dua variabel bebas ( partisipasi penyusunan anggran dan karakteristik tujuan anggaran) dan satu variabel moderasi (lingkungan kerja non fisik) sehingga penelitian yang akan datang perlu menambahkan beberapa variabel bebas lain yang relevan ( seperti motivasi kerja atau komitmen organisasi ) serta variabel moderasi (budaya organisasi).

Penelitian ini terbatas pada 14 SMK di Kota Semarang, agar lebih komprehensif analisisnya maka penelitian yang akan datang perlu dikembangkan dengan sampel yang lebih besar (seluruh SMK di Kota Semarang).

\section{Referensi}

Anoraga, Panji \& Widiyanto, Ninik .2002, Manajemen Sumber Daya Manusia - Konsep Dan Aplikasi, Yogyakarta : BPFE

Anthony dan Govindarajan. 2005. Management Control System, Edisi 11, Penerjemah: F.X. Kurniawan Tjakrawala, dan Krista. Jakarta : Penerbit Salemba Empat.

Arifian, Dhema. 2011. Pengaruh Intensitas R\&D dan Profitabilitas terhdap tanggung Jawab Sosial Perusahaan (Corporate Sosial Responsibility). Jurnal Ekonomi Universitas Diponegoro Semarang.

Arikunto, Suharsimi. 2006. Prosedur Penelitian Suatu Pendekatan Praktek (Revisi VI). Jakarta: Rineka Cipta.

Arikunto, Suharsimi. 2006. Prosedur Penelitian Suatu Pendekatan Praktek (Revisi VI). Jakarta: Rineka Cipta. 
Pengaruh Partisipasi Penyusunan Anggaran Dan Karakteristik Tujuan Anggaran Terhadap Kinerja Manajerial Dengan Lingkungan Kerja Non Fisik Sebagai Variabel Moderasi, VOL. 12. No. 1 KOMPAK Tahun 2019.

Azis, N. (2012). Analisis Pengaruh Partisipasi Penyusunan Anggaran, Kejelasan Anggaran Dan Umpan Balik Terhadap Peningkatan Kinerja Manajerial Melalui Kepuasan Kerja Dan Ketidakpastian Lingkungan Sebagai Variabel Moderating. Jurnal Analisis Manajemen, 5(1), 56-74.

Bhakti, D. C., Pituringsih, E., \& Widiastuty, E. 2015. Pengaruh Partisipasi Penyusunan Anggaran, Kejelasan Sasaran Anggaran, Dan Profesionalisme Sumber Daya Manusia Terhadap Kinerja Manajerial. In Assets (Vol. 5, No. 1, pp. 29-43).

Ferdinand, Agusty. 2006. Metode Penelitian Manajemen, Semarang :Badan Penerbit Universitas Diponegoro

Ghozali, Imam. 2011. SPSS 21 Aplikasi Analisis Multivariate Dengan Program SPSS Edisi 7.Semarang: BP Universitas Diponegoro

Jensen, M. C., \& Meckling, W. H. (1976). Theory of the Firm: Managerial Behavior, Agency Costs and Ownership

Structure. Journal ofFinancial

Economics, 3(4), 305-360.

Kenis, I. 1979. Effect of Budgetary Goal Characteristics on Managerial Attitues and
Performance. The

Accounting Review, Vol. LIV No. 4.October: 707721.

Khotimah, S. (2010). Pengaruh Karakteristik Tujuan Anggaran Terhadap Kinerja Manajerial Pada Satuan Kerja Perangkat Daerah (Skpd) Kabupaten Blora Dengan Komitmen Organisasi Sebagai Variabel Moderating Variabel Moderating(Doctoral

Dissertation, Universitas Negeri Semarang).

Khotimah, Siti. 2011. Pengaruh Partikularitas Tujuan Anggaran Terhadap Kinerja Manajerial Pada Satuan Kerja Perangkat Daerah (SKPD) Kabupaten Blora Dengan Komitmen Organisasi Sebagai Variabel Moderating. Jurnal Ekonomi Universitas Negeri Semarang.

Kurnia, R. .2004. Pengaruh Budgetary Goal Characteristics terhadap Kinerja Manajerial Dengan Lingkungan dan Komitmen Organisasi sebagai Variabel Moderating. Simposium Nasional Akuntansi (SNA) VII. Denpasar Bali, 15-16.

Kusumawati, N. N. .2016. Analisis Pengaruh Partisipasi Penyusunan Angaran Terhadap Kinerja Manajerial Dinas Bina Marga Kabupaten 
Pengaruh Partisipasi Penyusunan Anggaran Dan Karakteristik Tujuan Anggaran Terhadap Kinerja Manajerial Dengan Lingkungan Kerja Non Fisik Sebagai Variabel Moderasi, VOL. 12. No. 1 KOMPAK Tahun 2019.

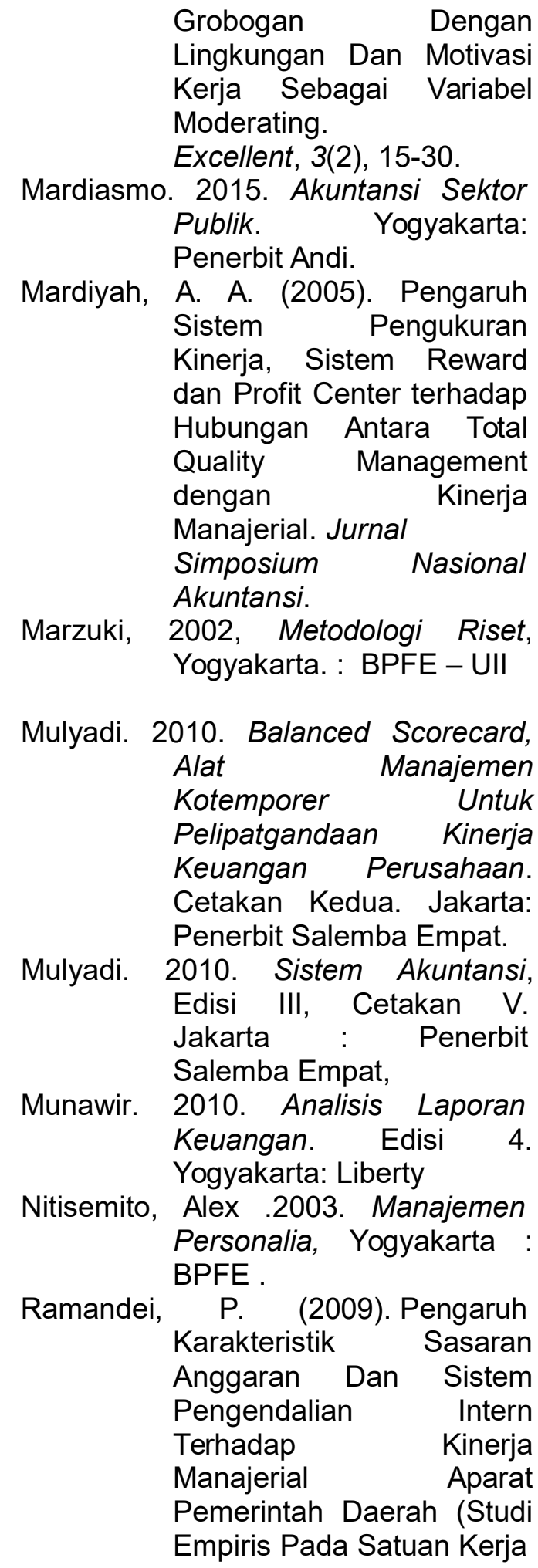

Perangkat Daerah Kota Jayapura) (Doctoral

Dissertation, Diponegoro University).

Sardjito B \& Muthaher O. 2007. Pengaruh Partisipasi Penyusunan Anggaran Terhadap Kinerja Aparat Pemerintah Daerah, Budaya Organisasi dan Komitmen Organisasi Sebagai Variabel Moderating, SNA $X$, Makassar.

Sasongko, Catur dan Safrida R. R Parulian. 2013. Anggaran. Jakarta : Salemba Empat.

Sucirawati, I.G.A \& Sari, M.M.R Pengaruh partipasi Penganggaran Terhadap Kinerja Manajerial Dengan Budaya Organisasi Dan Job Relevant Information Sebagai Pemoderasi. EJurnal Akuntansi, 1791 1891.

Sugiyono. 2004. Statiska Untuk Penelitian. Bandung: Alfabeta

Sumarno, J. (2005). Pengaruh Komitmen Organisasi Dan Gaya Kepemimpinan Terhadap Hubungan Antara Partisipasi Anggaran Dan Kinerja Manajerial (Studi Empiris Pada Kantor Cabang Perbankan Indonesia Di Jakarta). Jurnal Bisnis Strategi, 14(2), 197-210.

Umar, Husein. 2009. Metode Penelitian untuk Skripsi dan Tesis Bisnis. Jakarta: Rajawali Press. 
Pengaruh Partisipasi Penyusunan Anggaran Dan Karakteristik Tujuan Anggaran Terhadap Kinerja Manajerial Dengan Lingkungan Kerja Non Fisik Sebagai Variabel Moderasi, VOL. 12. No. 1 KOMPAK Tahun 2019.

Wahyudin, Nor. 2007. Desentralisasi

Dan Gaya Kepemimpinan

Sebagai

Moderating

Hubungan

Partisipasi

Anggaran

Menejerial.

Nasional Akuntansi $X$ Makassar.

Yovita, Farah Marta. 2011. Pengaruh Pertumbuhan Ekonomi, Pendapatan Asli Daerah, dan Dana Alokasi Umum terhadap Pengalokasian
Anggaran Belanja Modal.Jurnal Ekonomi Universitas Diponegoro.

Yunita, L. D. .2001. Analisis Pengaruh Sistem Anggaran Partisipatif, Struktur Organisasi Desentralisasi Dan Perilaku Manajer Pada Kinerja Manajerial Studi Pada Pt Pos Indonesia (Persero) Wilayah VIII-Denpasar (Doctoral Dissertation, Program Pascasarjana Universitas Diponegoro). 